\title{
Hydrotreatment of Heavy Oil from Coal Liquefaction on Sulfided Ni-W Catalysts
}

\author{
Zhi-ping Lei, Li-juan Gao, Heng-fu Shui,* Shi-biao Ren, Zhi-cai Wang and \\ Kang-shi Gang
}

\author{
School of Chemistry \& Chemical Engineering, Anhui Key Laboratory of Coal Clean Conversion \& \\ Utilization, Anhui University of Technology, 243002 Ma'anshan, P. R. China
}

\begin{abstract}
Derivados de óleo pesado (temperatura de destilação: $320-340{ }^{\circ} \mathrm{C}$ ), obtidos a partir do processo de liquefação direta do carvão, usando carvão Shengli foram tratados com hidrogênio usando catalisadores sulfetados $\mathrm{Ni}-\mathrm{Mo} / \mathrm{Al}_{2} \mathrm{O}_{3}, \mathrm{Ni}-\mathrm{W} / \mathrm{Al}_{2} \mathrm{O}_{3} \mathrm{e} \mathrm{Ni}-\mathrm{W} / \mathrm{SiO}_{2}$ respectivamente. Os catalisadores sulfetados foram caracterizados por BET, XRD, $\mathrm{H}_{2}-\mathrm{TPR}$ e $\mathrm{NH}_{3}-\mathrm{TPD}$, respectivamente. As avaliações das propriedades de hidrodenitrogenação (HDN) e hidrodearomatização (HDA) do óleo pesado nos três catalisadores foram realizadas a $400{ }^{\circ} \mathrm{C}$ e $5,0 \mathrm{MPa}$ de pressão inicial de $\mathrm{H}_{2}$. Os catalisadores contendo W mostraram melhores desempenhos do que os catalisadores de Mo para as reações de HDN e HDA. Os catalisadores suportados em $\mathrm{Al}_{2} \mathrm{O}_{3}$ apresentaram maior atividade catalítica do que aqueles suportados em $\mathrm{SiO}_{2}$. As atividades dos catalisadores sulfetados foram associadas principalmente à natureza dos sítios ativos, acidez, tamanho do cristalito e da quantidade de espécies redutíveis de enxofre do sulfeto metálico.
\end{abstract}

Heavy oil (distillation temperature: $320-340{ }^{\circ} \mathrm{C}$ ) derived from the direct coal liquefaction process using Shengli coal were hydrotreated using sulfided $\mathrm{Ni}-\mathrm{Mo} / \mathrm{Al}_{2} \mathrm{O}_{3}, \mathrm{Ni}-\mathrm{W} / \mathrm{Al}_{2} \mathrm{O}_{3}$, and $\mathrm{Ni}-\mathrm{W} / \mathrm{SiO}_{2}$ catalysts respectively. The sulfided catalysts were characterized by BET, XRD, $\mathrm{H}_{2}-\mathrm{TPR}$ and $\mathrm{NH}_{3}-\mathrm{TPD}$ respectively. The evaluations of the hydrodenitrogenation (HDN) and hydrodearomatization (HDA) properties of heavy oil on the three catalysts were carried out at $400{ }^{\circ} \mathrm{C}$ and 5.0 $\mathrm{MPa}$ initial $\mathrm{H}_{2}$ pressure. The W-based catalysts displayed better performances than Mo-based catalysts for the HDN and HDA reactions. $\mathrm{Al}_{2} \mathrm{O}_{3}$ supported catalysts were found to have higher catalytic activities than on $\mathrm{SiO}_{2}$ supported ones. The activities of sulfided catalysts were associated mainly with the nature of active sites, acidity, metal sulfide crystallite size and the amount of the reducible sulfur species of metal sulfide.

Keywords: direct coal liquefaction, heavy oil, HDN, HDA

\section{Introduction}

With fast increasing demand in liquid transportation fuels and limited petroleum resources, production of transportation fuels from direct coal liquefaction (DCL) technologies has been an important option to lessen the deficiency in petroleum supply. ${ }^{1}$

The liquid product obtained from direct coal liquefaction has low hydrogen to carbon ratio and contains a considerable amount of heteroatom compounds that may cause many troubles such as instability of fuel during its transportation or storage. ${ }^{2}$ Nitrogen compounds are certainly an inhibitor in hydrotreatment and cracking processes of these stocks, ${ }^{3,4}$ and lead the catalysts used in the downstream secondary processing (such as fluid catalytic cracking and

*e-mail: shhf@ ahut.edu.cn hydrocracking) deactivate faster. Such a product must be upgraded to become a feedstock for the existing refineries through extensive removal of heteroatom contained molecules, principally $\mathrm{N}, \mathrm{S}$ and $\mathrm{O}$ in aromatic rings, over sulfided $\mathrm{Ni}-\mathrm{Mo}$ or $\mathrm{Co}-\mathrm{Mo}$ catalysts to the acceptable levels in petroleum refining. Moreover the refined products must satisfy the various requirements to be sold in the market, such as cetane index, aromatic content, and sulfur content. Thus, the higher content of nitrogen compounds present in the coal derived heavy oil should be removed prior to further processing.

The aromatic nature of DCL products may be another challenge. Although it can be upgraded to meet all the current specifications for transportation fuels, it may be difficult to keep up with the increasingly stringent specifications in future at an acceptable cost. Novel products upgrading techniques are much needed. ${ }^{1}$ Advanced refinery 
technologies, such as hydrodearomatization (HDA), must be implemented in order to fulfill the limits for aromatic contents. Cetane number can also be increased by the HDA process. The hydrogenation of polyaromatics is the main issue in upgrading of coal-derived liquid. Hydrogenation of aromatics is more difficult than hydrodesulfurization (HDS) and hydrodenitrogenation (HDN) due to the types and amount of aromatic species present in the oil as well as the complexity of the reactions. ${ }^{5}$

Many studies have been conducted to investigate the hydrotreatment of coal-derived product on various catalysts. ${ }^{6-12}$ However, few studies focus on the HDA activities on the typical sulfided catalysts based on our knowledge. Industrial HDN and HDS processes have been largely carried out over sulfided Mo-based catalysts promoted with $\mathrm{Ni}$ or Co and supported on $\gamma$-alumina. However, HDN for high nitrogen content of heavy oil is more difficult and less effective with conventional Ni$\mathrm{Mo} / \mathrm{Al}_{2} \mathrm{O}_{3}$ catalyst. ${ }^{13}$ Yoshimura et al. ${ }^{14}$ found that $\mathrm{NiW}$ displays higher HDA activity provided the $\mathrm{H}_{2}$ pressure is high and the $\mathrm{H}_{2} \mathrm{~S}$ pressure is moderate to low. Compared to molybdenum-based catalysts, the hydrotreating catalysts based on tungsten are relatively less studied, especially for upgrading of coal-derived liquid.

In this study, the three sulfided catalysts $(\mathrm{Ni}-\mathrm{Mo} /$ $\mathrm{Al}_{2} \mathrm{O}_{3}, \mathrm{Ni}-\mathrm{W} / \mathrm{Al}_{2} \mathrm{O}_{3}$ and $\mathrm{Ni}-\mathrm{W} / \mathrm{SiO}_{2}$ ) were prepared and characterized by BET (Brunner, Emmet, Teller method), XRD (X-ray diffraction patterns), $\mathrm{H}_{2}-\mathrm{TPR}$ (temperature programmed reduction) and $\mathrm{NH}_{3}-\mathrm{TPD}$ (temperature programmed desorption), respectively. The hydrogenation activity (especially the HDN and HDA activities) of the three sulfided catalysts was evaluated for upgrading of direct coal liquefaction heavy oil.

\section{Experimental}

The Shengli coal-derived heavy oil (HO) used was generated from direct liquefaction of Shengli coal in a 0.1 ton/day continuous unit at China Coal Research Institute, Beijing. The direct coal liquefaction reactor was operated at $455{ }^{\circ} \mathrm{C}$ and $19 \mathrm{MPa}$ in the presence of Shenhua Fe-based catalyst. The direct coal liquefaction products were separated through high-temperature and low-temperature separators, followed by atmospheric and vacuum distillations. The $\mathrm{HO}$ (boiling point: $320-340{ }^{\circ} \mathrm{C}$ ) used in this study was the narrow fraction of Shengli coal-derived liquid, which are gained by the ture boiling point distillation and has high aromatic content (47 wt \%) and high nitrogen content $(0.4 \mathrm{wt} \%)$.

The support material, $\mathrm{Al}_{2} \mathrm{O}_{3}$ and $\mathrm{SiO}_{2}$ were provided by Fushun Petrochemical Co. (BET surface area of $185 \mathrm{~m}^{2} \mathrm{~g}^{-1}$ ) and Qindao Ocean Chemical Plant (BET surface area of $408 \mathrm{~m}^{2} \mathrm{~g}^{-1}$ ), respectively.

The loading of Ni-W and Ni-Mo was carried out by incipient wetness impregnation of the support using mixed solutions of ammonium metatungstate and nickel(II) citrate in the case of the Ni-W catalysts, or a mixed solution of ammonium heptamolybdate and nickel(II) citrate for the Ni-Mo catalysts. The impregnated sample was dried and calcined at $500{ }^{\circ} \mathrm{C}$ for $3 \mathrm{~h}$. These calcined precursors were then sulfided at $400{ }^{\circ} \mathrm{C}$ with a $\mathrm{CS}_{2} / \mathrm{H}_{2}$ gas $\left(10 / 90 \%, 60 \mathrm{~mL} \mathrm{~min}^{-1}\right)$ for $2 \mathrm{~h}$. The sulfided catalysts were subsequently reduced under $\mathrm{H}_{2}$ flow for $2 \mathrm{~h}$ at $400{ }^{\circ} \mathrm{C}$ for evaluating the hydrotreating activities in the batch runs. The sample was then cooled to room temperature and passivated in stream of $1 \% \mathrm{O}_{2}$ for $6 \mathrm{~h}$. The prepared $\mathrm{Ni}-\mathrm{W}$ or Ni-Mo catalyst contains $5 \mathrm{wt} . \% \mathrm{Ni}$ and $15 \mathrm{wt} . \% \mathrm{~W}$ or Mo.

BET surface area of the sulfided catalyst was determined by nitrogen adsorption at $-196{ }^{\circ} \mathrm{C}$ using an ASAP2000 volumetric adsorption analyzer. Total pore volume was calculated from the amount of nitrogen adsorbed at a relative $\mathrm{N}_{2}$ pressure $\left(\mathrm{P}_{0}^{-1}\right)$ of 0.99 . The average pore size was assumed to be $4 \mathrm{~V} / \mathrm{BET}$. All the samples were degassed at $150{ }^{\circ} \mathrm{C}$ for $12 \mathrm{~h}$ before the measurement.

The acidity of the prepared sulfided catalyst was studied by $\mathrm{NH}_{3}$ temperature programmed desorption $\left(\mathrm{NH}_{3}-\mathrm{TPD}\right)$ in Quantachrome ChemBET-3000 instrument. $0.1 \mathrm{~g}$ of sample was loaded into a tubular reactor, and then purged for $2 \mathrm{~h}$ with $40 \mathrm{~mL} \mathrm{~min}^{-1}$ helium at $773 \mathrm{~K}$ (increased from ambient temperature to $773 \mathrm{~K}$ at $10 \mathrm{~K} \mathrm{~min}^{-1}$ ), followed by lowering temperature to $353 \mathrm{~K}$. Gaseous ammonia $\left(50 \mathrm{~mL} \mathrm{~min}{ }^{-1}\right)$ mixed with helium ( $40 \mathrm{~mL} \mathrm{~min}^{-1}$ ) was charged for $30 \mathrm{~min}$ at $353 \mathrm{~K}$, and then purged with $40 \mathrm{~mL} \mathrm{~min}^{-1} \mathrm{He}$ at $373 \mathrm{~K}$ for $1 \mathrm{~h}$. Under the $40 \mathrm{~mL} \mathrm{~min}^{-1}$ of helium, the temperature was raised from 373 to $883 \mathrm{~K}$ at $15 \mathrm{~K} \mathrm{~min}^{-1}$.

Temperature programmed reduction $\left(\mathrm{H}_{2}-\mathrm{TPR}\right)$ experiments were carried out in a smaller fixed-bed quartz reactor $(2 \mathrm{~mm}$ i.d.) coupled with the Hiden QIC-20 mass spectrometer. The transfer line between the fixed-bed reactor and the mass spectrometer was kept at $180{ }^{\circ} \mathrm{C}$. Sulfided samples of $90 \mathrm{mg}$ were heated from room temperature to $800^{\circ} \mathrm{C}$ at a rate of $10^{\circ} \mathrm{C} \mathrm{min}^{-1}$ under a flow of $5 \% \mathrm{H}_{2} / \mathrm{Ar}\left(50 \mathrm{~mL} \mathrm{~min}{ }^{-1}\right)$. The evolution of $\mathrm{H}_{2} \mathrm{~S}$ was analyzed by mass spectrometer.

X-ray diffraction patterns (XRD) of sulfided catalysts were obtained on a Rigaku computer-controlled D/max $2500 \times$ using $\mathrm{Cu}-\mathrm{K} \alpha$ as the radiation source. During the analysis, catalysts were scanned from 10 to $80^{\circ}$ at a speed of $4^{\circ} \mathrm{min}^{-1}$.

The hydrogenation experiments of Shengli coal-derived heavy oil were carried out in a $30 \mathrm{~mL}$ tubing reactor shaken vertically. $3.0 \mathrm{~g}$ of heavy oil was charged into the reactor 
together with $0.15 \mathrm{~g}$ of sulfided catalyst, which simulates typical online hydrotreating conditions for heavy liquids in direct coal liquefaction with an initial $\mathrm{H}_{2}$ pressure of $5 \mathrm{MPa}$ and a temperature of $400{ }^{\circ} \mathrm{C}$. After loading the sample, the reactor was sealed and flushed 3 times with hydrogen followed by tuning the system to the desired initial pressure of $5 \mathrm{MPa} \mathrm{H}_{2}$. The reactor, agitated vertically at $120 \mathrm{rpm}$, was submerged into a eutectic salt bath, which had been heated to the desired temperature and maintained for $60 \mathrm{~min}$. After the reaction, the reactor was quenched to ambient temperature in a water bath before the overhead pressure in the reactor was released slowly. The liquid and catalyst in the reactor were removed and separated by centrifugation.

Carbon, nitrogen, and hydrogen analyses were performed using a Elementar Vario EL III. The liquid samples in elemental analysis were sealed in the capsule. Air in the capsule was forced out the capsule via a gas stream of oxygen. The mean blank values of several samples were subtracted for evaluation.

Aromatic distribution analysis was carried out on Shimadzu LC-2000 high performance liquid chromatography with an UV detector $(\lambda=254 \mathrm{~nm})$. A Sepax $\mathrm{NH}_{2}$ (30 cm length, $0.8 \mathrm{~cm}$ i.d.) separation column was operated isothermally at $25{ }^{\circ} \mathrm{C}$. Hexane was used as the mobile phase with a flow rate of $1.2 \mathrm{~mL} \mathrm{~min}^{-1}$. The identification of aromatic components (biaromatic and triaromatic) was carried out by the retention time of selected representative components of the mono, di and triaromatic groups (toluene, naphthalene, anthracene and phenanthrene).

\section{Results and Discussion}

The BET surface area, pore volume and pore size distribution of three sulfided catalysts are given in Table 1. It shows that the drastic reduction of the specific surface area was observed. Compared to the specific surface areas of supports, the specific surface areas of sulfided $\mathrm{N}-\mathrm{Mo} /$ $\mathrm{Al}_{2} \mathrm{O}_{3}, \mathrm{Ni}-\mathrm{W} / \mathrm{Al}_{2} \mathrm{O}_{3}$ and $\mathrm{Ni}-\mathrm{W} / \mathrm{SiO}_{2}$ catalysts decreased by about $33 \%, 21 \%$ and $40 \%$ respectively. This decrease in specific surface area could be attributed to the lower amount of support in the catalyst (only about $70 \%$ of the catalyst is support and contributes for the surface area) and the presence of particles of Ni-W(Mo)-S and WS2 or MoS2 partially blocking the mesopores. Compared to $\mathrm{Ni}-\mathrm{W} / \mathrm{Al}_{2} \mathrm{O}_{3}$, $\mathrm{Ni}-\mathrm{Mo} / \mathrm{Al}_{2} \mathrm{O}_{3}$ shows lower surface area, pore volume and mean pore radius, revealing a poor dispersion of the actives phases or a higher blockage of mesopores. For $\mathrm{Ni}-\mathrm{W}$ based catalyst, $\mathrm{Al}_{2} \mathrm{O}_{3}$ supported catalyst displayed higher pore volume and mean pore radius compared to $\mathrm{SiO}_{2}$ supported one. The observed textural differences can be attributed to the differences of the active phase and the type of support.

The $\mathrm{N}_{2}$ adsorption-desorption isotherms of sulfided catalysts are shown in Figure 1. All the sulfided catalysts exhibited the typical type IV isotherms according to the Brunauer-Deming-Deming-Teller (BDDT) classification, which exhibited the condensation and evaporation step characteristic of common mesoporous materials. The pore diameter distribution curves of the samples are shown in Figure 2. Compared with the $\mathrm{Ni}-\mathrm{Mo} / \mathrm{Al}_{2} \mathrm{O}_{3}$ catalyst it clearly shows that $\mathrm{Ni}-\mathrm{W} / \mathrm{Al}_{2} \mathrm{O}_{3}$ exhibited a bimodal distribution of pore size, which may indicate that the addition of W mainly blocks the mesopores. For Ni-W/SiO sample, the pore diameter ranges were narrow (between $3 \mathrm{~nm}$ and $15 \mathrm{~nm})$.

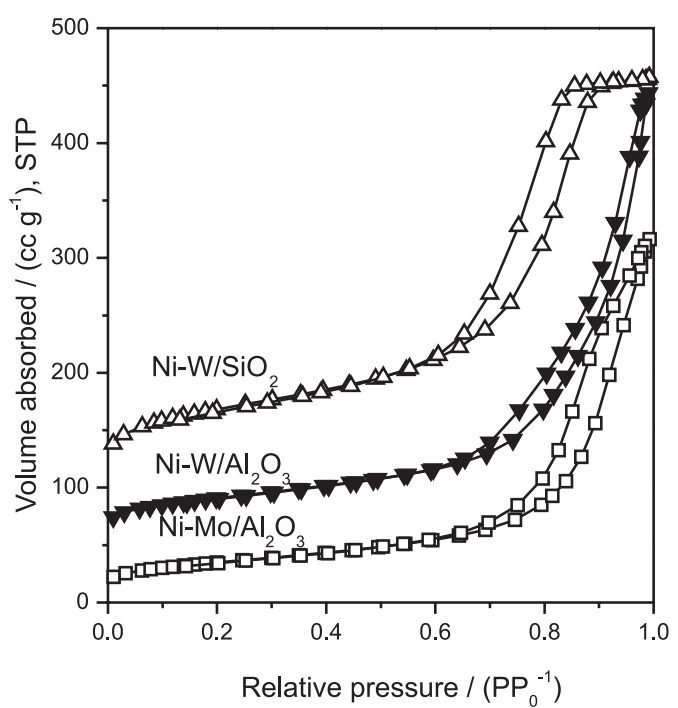

Figure 1. The nitrogen-adsorption/desorption isotherms of sulfided catalysts.

Figure 3 shows the $\mathrm{X}$-ray diffraction patterns of the three sulfided catalysts. It can be seen that two $\mathrm{Al}_{2} \mathrm{O}_{3}$-based catalysts display only broad peaks of the alumina support. No characteristic peaks of $\mathrm{NiS}_{2}, \mathrm{MoS}_{2} / \mathrm{WS}_{2}$ phases, NiO

Table 1. Textural property of sulfided catalysts

\begin{tabular}{lccc}
\hline Catalyst & Surface area $/\left(\mathrm{m}^{2} \mathrm{~g}^{-1}\right)$ & Pore volume $/\left(\mathrm{cm}^{3} \mathrm{~g}^{-1}\right)$ & Mean pore radius / $\mathrm{nm}$ \\
\hline $\mathrm{Ni}-\mathrm{Mo} / \mathrm{Al}_{2} \mathrm{O}_{3}$ & 124 & 0.489 & 15.8 \\
$\mathrm{Ni}-\mathrm{W} / \mathrm{Al}_{2} \mathrm{O}_{3}$ & 147 & 0.609 & 16.6 \\
$\mathrm{Ni}-\mathrm{W} / \mathrm{SiO}_{2}$ & 246 & 0.553 & 9.0 \\
\hline
\end{tabular}




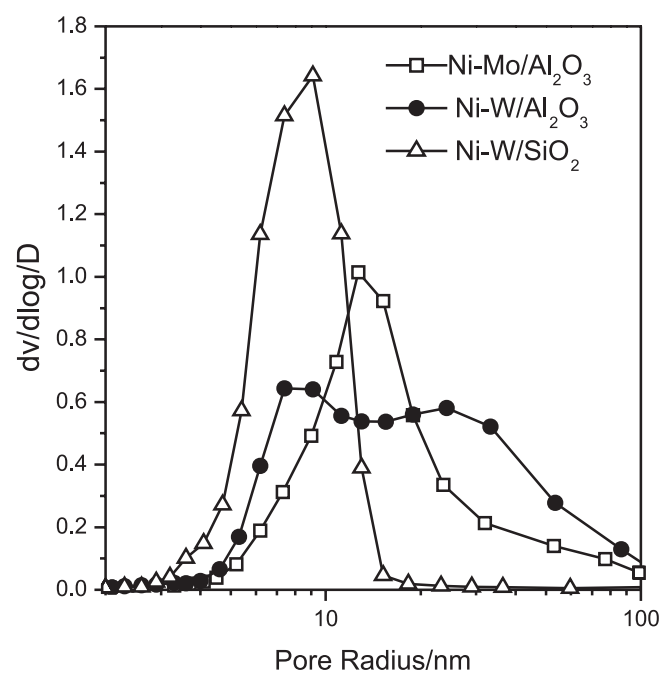

Figure 2. The pore size distributions of sulfided catalysts.

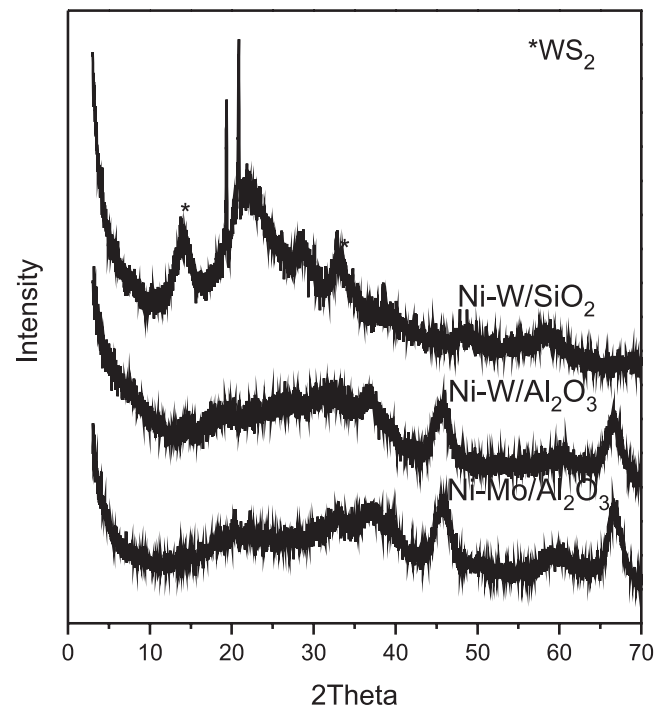

Figure 3. X-ray diffraction patterns of sulfided catalysts.

and $\mathrm{MoO}_{3} / \mathrm{WO}_{3}$, metallic nickel /tungsten phase can be observed. This indicates that $\mathrm{Ni}$ and $\mathrm{Mo} / \mathrm{W}$ species were considered uniformly distributed on the surface of the $\mathrm{Al}_{2} \mathrm{O}_{3}$ support under preparation conditions. Also, the absence of diffraction lines of nickel or tungsten sulfide could indicate that these phases have a very small particle size or that they are inserted into the structure of $\mathrm{WS}_{2}$ or $\mathrm{MoS}_{2}$, forming a well dispersed Ni-W(Mo)-S nanoclusters. ${ }^{15}$ But for $\mathrm{Ni}-\mathrm{W} / \mathrm{SiO}_{2}$ catalyst, the $\mathrm{WS}_{2}$ phases can be confirmed. This result indicates that the $\mathrm{SiO}_{2}$ support led to larger size of W cluster size, which may result from the temperature of calcinations for $\mathrm{SiO}_{2}$ is too high.

The TPD of $\mathrm{NH}_{3}$ is a useful tool to measure the acidity and its distribution of the catalyst. The $\mathrm{NH}_{3}-\mathrm{TPD}$ profiles for the three sulfided catalysts are completely different as shown in Figure 4. To compare the acidity distribution

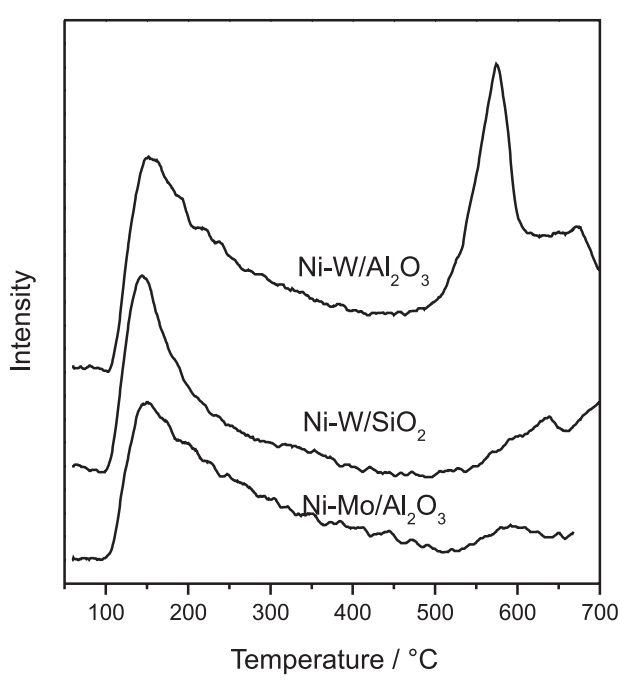

Figure 4. The $\mathrm{NH}_{3}$-TPD profiles of sulfided catalysts.

among the catalysts, the weak, medium, and strong acidities were assigned to the peak areas of $\mathrm{NH}_{3}-\mathrm{TPD}$ curves below $623 \mathrm{~K}$, at $623-773 \mathrm{~K}$, and above $773 \mathrm{~K}$, respectively. ${ }^{16}$ The sulfided $\mathrm{Ni}-\mathrm{Mo} / \mathrm{Al}_{2} \mathrm{O}_{3}$ catalyst showed one broad peak at the temperature range of $100-500{ }^{\circ} \mathrm{C}$, which is attributes to the weak acid sites (74\%) and medium acid sites (14\%). The sulfided $\mathrm{Ni}-\mathrm{W} / \mathrm{SiO}_{2}$ catalyst showed an increase both in the strong acid sites by $10 \%$, compared to the sulfided $\mathrm{Ni}-\mathrm{Mo} /$ $\mathrm{Al}_{2} \mathrm{O}_{3}$ catalyst. The sulfided $\mathrm{Ni}-\mathrm{W} / \mathrm{Al}_{2} \mathrm{O}_{3}$ catalyst showed significant increase of amount of the strong acid sites by $23 \%$ compared to the sulfided Ni-W/SiO 2 catalyst. The $\mathrm{NH}_{3}-\mathrm{TPD}$ results confirm the significant difference of acid sites on the sulfided catalyst surface. Several works proved that strong acid sites are closely related to hydrogenation activity. The strong acid site is probably due to the formation of another active phase on the catalyst, which reduces the interaction between $\mathrm{NiMoS}$ and $\mathrm{Al}_{2} \mathrm{O}_{3} \cdot{ }^{17}$ Many literatures ${ }^{18,19}$ proved that strong acid sites on the catalyst surface are responsible for the enhancement of HDN activity of the catalysts. The higher acidity led to higher conversion.

The TPR was performed for three sulfided catalysts to study the extent of a reaction of hydrogen with the sulfide species present on the sulfided catalyst surface. Figure 5 shows the evolution of $\mathrm{H}_{2} \mathrm{~S}$ during $\mathrm{H}_{2}-\mathrm{TPR}$ processes. The evolution peak of $\mathrm{H}_{2} \mathrm{~S}$ is probably due to the reaction of $\mathrm{NiS}_{2}$, $\mathrm{MoS}_{2}$ or $\mathrm{WS}_{2}$ with $\mathrm{H}_{2}{ }^{18}$ It can be seen that the three samples showed quite different behaviors in $\mathrm{H}_{2} \mathrm{~S}$ evolution profiles. For the sulfided $\mathrm{Ni}-\mathrm{Mo} / \mathrm{Al}_{2} \mathrm{O}_{3}$ catalyst there were mainly two $\mathrm{H}_{2} \mathrm{~S}$ evolution peaks, which were in the temperature ranges of $100-250{ }^{\circ} \mathrm{C}$ and $350-700{ }^{\circ} \mathrm{C}$, respectively. The sulfided $\mathrm{Ni}-\mathrm{W} / \mathrm{SiO}_{2}$ catalyst also had two $\mathrm{H}_{2} \mathrm{~S}$ evolution peaks during $\mathrm{H}_{2}$-TPR process, but the temperature ranges shifted to $150-400$ and $500-800{ }^{\circ} \mathrm{C}$ compared to the sulfided $\mathrm{Ni}-\mathrm{Mo} / \mathrm{Al}_{2} \mathrm{O}_{3}$ catalyst, respectively. The sulfided Ni-W/ 


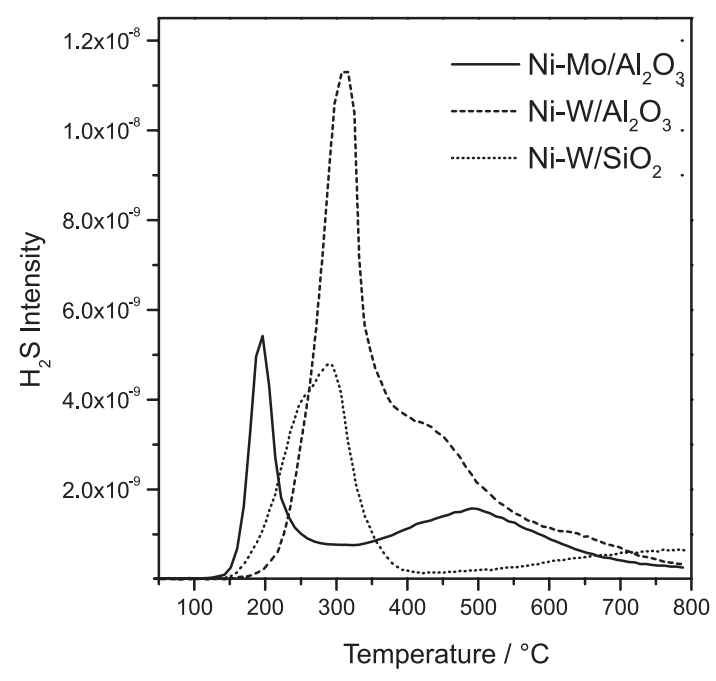

Figure 5. $\mathrm{H}_{2}$-TPR profiles for sulfided catalysts.

$\mathrm{Al}_{2} \mathrm{O}_{3}$ catalyst showed significant increase of amount of $\mathrm{H}_{2} \mathrm{~S}$ evolution between 200 to $800^{\circ} \mathrm{C}$, compared to the sulfided $\mathrm{Ni}-\mathrm{Mo} / \mathrm{Al}_{2} \mathrm{O}_{3}$ and $\mathrm{Ni}-\mathrm{W} / \mathrm{SiO}_{2}$. The $\mathrm{H}_{2} \mathrm{~S}$ evolution peak for $\mathrm{Ni}-\mathrm{W} / \mathrm{Al}_{2} \mathrm{O}_{3}$ was larger than those of $\mathrm{Ni}-\mathrm{Mo} / \mathrm{Al}_{2} \mathrm{O}_{3}$ and $\mathrm{Ni}-\mathrm{W} / \mathrm{SiO}_{2}$, indicating much reduction of $\mathrm{WS}_{2}$ and $\mathrm{NiS}_{2}$. Nag et al. ${ }^{20}$ suggested that surface reaction between surface anion and $\mathrm{H}_{2}$ forms surface anion vacancy, which has been frequently suggested as catalytic active sites for HDS and other hydroprocessing reactions.

The HO used in this experiment, which is characterized by high aromatic content and high nitrogen content, is a typical coal-derived liquid feed stock for hydrotreatment. The color of $\mathrm{HO}$ as received is black. After hydrogenation, the color of HO turned from black to yellow. During prolonged storage of hydrogenated $\mathrm{HO}$ it was found that the color of $\mathrm{HO}$ after hydrogenation slowly turned from yellow to black, especially in air, which agrees with Begon's finding. ${ }^{21}$ But $\mathrm{HO}$ hydrogenated on $\mathrm{Ni}-\mathrm{W} / \mathrm{Al}_{2} \mathrm{O}_{3}$ catalyst is more stable than that of others (as shown in Figure 6), which

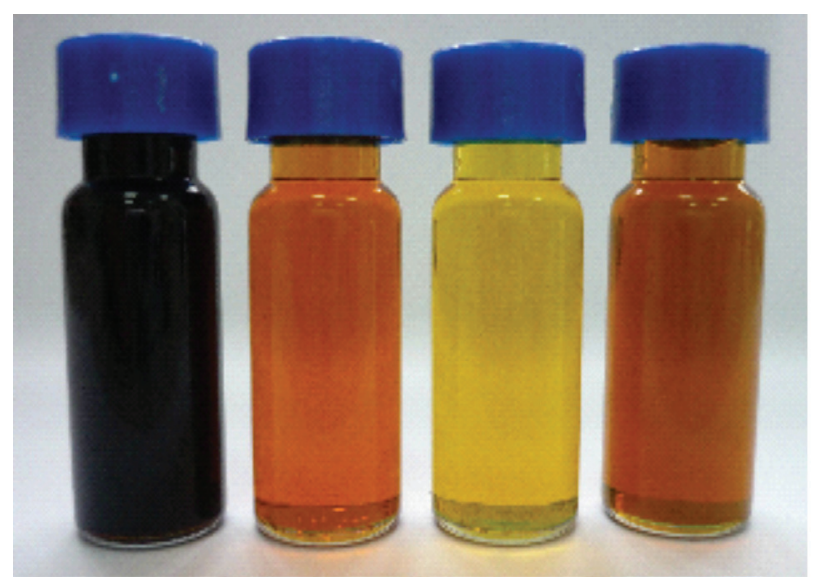

Figure 6. Photos of heavy oil (HO) and its hydrogenation products on sulfided catalysts. indicates that the catalyst structures affect the stability of heavy oil after hydrotreatment. Further work on the storage stability of coal-derived liquid has been carrying out in our laboratory.

Figure 7 shows the HDN activities of the three sulfided catalysts. It shows that HDN conversion of sulfided $\mathrm{Ni}-\mathrm{Mo} / \mathrm{Al}_{2} \mathrm{O}_{3}$ catalyst was $27 \%$, which indicates that the nitrogen of $\mathrm{HO}$ is difficult to remove. Compared with sulfided $\mathrm{Ni}-\mathrm{Mo} / \mathrm{Al}_{2} \mathrm{O}_{3}$ catalyst, sulfided $\mathrm{Ni}-\mathrm{W} /$ $\mathrm{Al}_{2} \mathrm{O}_{3}$ catalyst and $\mathrm{Ni}-\mathrm{W} / \mathrm{SiO}_{2}$ exhibited much higher HDN activity. The HDN activities of sulfided Ni-W/ $\mathrm{Al}_{2} \mathrm{O}_{3}$ and $\mathrm{Ni}-\mathrm{W} / \mathrm{SiO}_{2}$ catalysts increased by $33 \%$ and $10 \%$, respectively compared to that of $\mathrm{Ni}-\mathrm{Mo} / \mathrm{Al}_{2} \mathrm{O}_{3}$. These results indicate that $\mathrm{W}$-based sulfided catalysts have higher HDN activity than that of Mo-based sulfide catalysts towards coal-derived heavy oil hydrogenation and the type of support also significantly affect of HDN activity. Higher $\mathrm{HDN}$ activities were found on the $\mathrm{Al}_{2} \mathrm{O}_{3}$ than those on $\mathrm{SiO}_{2}$ supported catalysts.

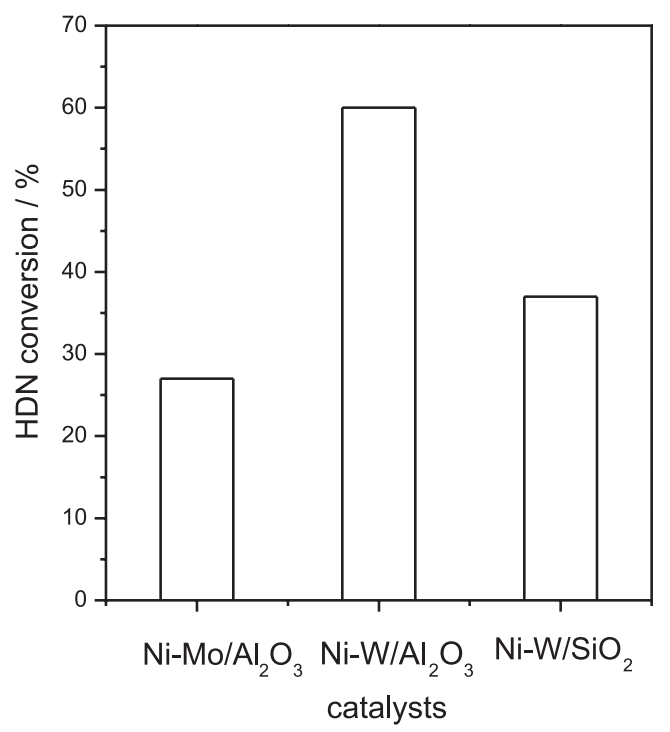

Figure 7. HDN conversion of $\mathrm{HO}$ over sulfided catalysts.

Another aim of $\mathrm{HO}$ hydrogenation is to increase the $\mathrm{H} / \mathrm{C}$ atomic ratio of product. Figure 8 shows the H/C atomic ratio of $\mathrm{HO}$ before and after hydrogenation on three sulfide catalysts. It can be seen that the change of $\mathrm{H} / \mathrm{C}$ atomic ratio after hydrogenation on three sulfide catalysts was significantly different. Sulfided Ni-Mo/ $\mathrm{Al}_{2} \mathrm{O}_{3}$ caused only small increment of the $\mathrm{H} / \mathrm{C}$ ratio. As compared to sulfided $\mathrm{Ni}-\mathrm{Mo} / \mathrm{Al}_{2} \mathrm{O}_{3}$ catalyst, the $\mathrm{H} / \mathrm{C}$ ratio was significantly increased for $\mathrm{Ni}-\mathrm{W} / \mathrm{Al}_{2} \mathrm{O}_{3}$ catalyst and $\mathrm{Ni}-\mathrm{W} / \mathrm{SiO}_{2}$, and the highest $\mathrm{H} / \mathrm{C}$ ratio was obtained for $\mathrm{Ni}-\mathrm{W} / \mathrm{Al}_{2} \mathrm{O}_{3}$. The result of the change of $\mathrm{H} / \mathrm{C}$ atomic ratio indicates that the hydrogenation activities follow the order: $\mathrm{Ni}-\mathrm{W} / \mathrm{Al}_{2} \mathrm{O}_{3}>\mathrm{Ni}-\mathrm{W} / \mathrm{SiO}_{2}>\mathrm{Ni}-\mathrm{Mo} / \mathrm{Al}_{2} \mathrm{O}_{3}$. 


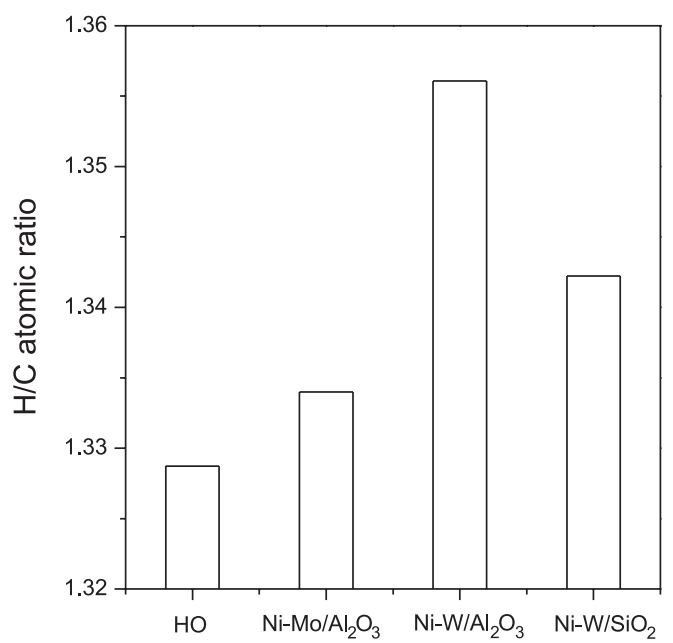

Figure 8. $\mathrm{H} / \mathrm{C}$ atomic ratio of $\mathrm{HO}$ and its hydrogenation products over sulfided supported catalysts.

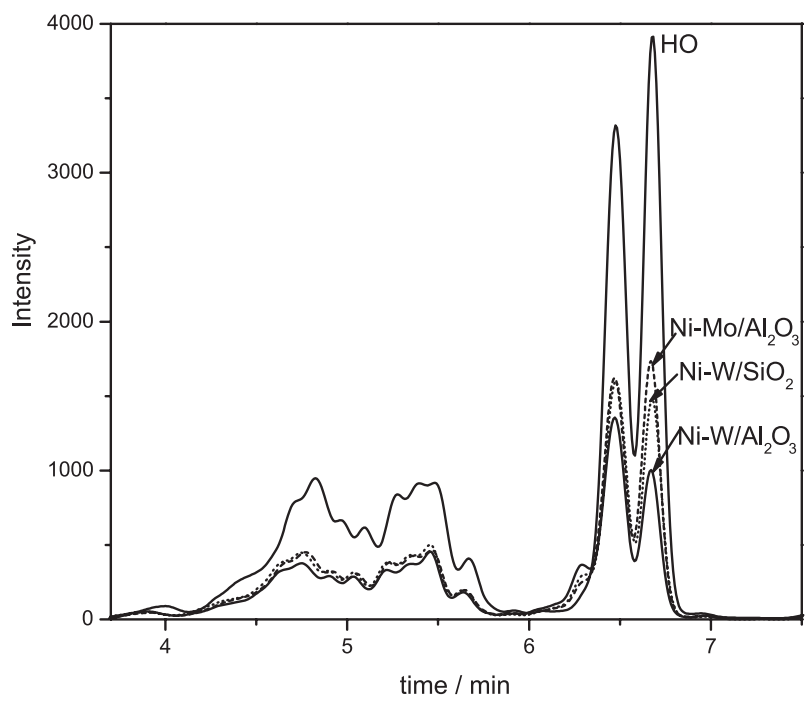

Figure 9. Aromatic distribution of $\mathrm{HO}$ and its hydrogenation products on different catalysts.

Figure 9 shows the aromatic distribution of the feedstock (HO) and its hydrogenation products on the three sulfided catalysts. It shows that aromatic of $\mathrm{HO}$ mainly contained diaromatics (naphthalene and its derived) and triaromatics (anthracene and phenanthrene). After hydrogenation, the amounts of aromatic significantly decreased on all the catalysts. Table 2 shows the HDA activities of three sulfided catalysts. It shows that the HDA activies of sulfided $\mathrm{Ni}-\mathrm{Mo} /$ $\mathrm{Al}_{2} \mathrm{O}_{3}, \mathrm{Ni}-\mathrm{W} / \mathrm{Al}_{2} \mathrm{O}_{3}$ and $\mathrm{Ni}-\mathrm{W} / \mathrm{SiO}_{2}$ catalysts were $50 \%$,
$58 \%$ and $50 \%$, respectively. For sulfided $\mathrm{Ni}-\mathrm{Mo} / \mathrm{Al}_{2} \mathrm{O}_{3}$, the HDA activities of diaromatics and triaromatics were almost the same. But for sulfided $\mathrm{Ni}-\mathrm{W} / \mathrm{Al}_{2} \mathrm{O}_{3}$ and $\mathrm{Ni}-\mathrm{W} / \mathrm{SiO}_{2}$ catalysts the HDA activities of triaromatics were higher than that of diaromatics by $5 \%$. This result indicates that active phase-W can significantly increase HDA activities of triaromatics compared with that of diaromatics. In order to gain some insights into the reactivity of HO, the HDA activity of triaromatic (anthracene and phenanthrene) were calculated in Table 2. It can be seen that hydrogenation of $\mathrm{HO}$ on the sulfided $\mathrm{Ni}-\mathrm{Mo} / \mathrm{Al}_{2} \mathrm{O}_{3}$ resulted in a $49 \%$ and $55 \%$ decrease of anthracene and phenanthrene, respectively. In the presence of $\mathrm{Ni}-\mathrm{W} / \mathrm{SiO}_{2}$ the conversions of anthracene and phenanthrene were $49 \%$ and $61 \%$, respectively. However, in the presence of $\mathrm{Ni}-\mathrm{W} / \mathrm{Al}_{2} \mathrm{O}_{3}$ the conversions of anthracene and phenanthrene were 55\% and 74\%, respectively. These results indicate that active phase-W can significantly increase the hydrogenation of phenanthrene for about 19\% compare to that of active phase-Mo. Also Absi-Halabi et al. ${ }^{22}$ found that asphaltene conversion for $\mathrm{Ni}-\mathrm{W} / \mathrm{Al}_{2} \mathrm{O}_{3}$ was higher than that of $\mathrm{Ni}-\mathrm{Mo} / \mathrm{Al}_{2} \mathrm{O}_{3}$ during hydrotreating of petroleum residues. However, it should be noted that the presence of polyaromatic compounds could lead to coke formation, which can lead to catalyst deactivation. Further testing should be required to explore the deactivation of W-based catalysts.

From the above characterizations of three sulfided catalysts it can be observed that $\mathrm{Ni}-\mathrm{W} / \mathrm{Al}_{2} \mathrm{O}_{3}$ had higher pore volume and larger pore size, which indicates that $\mathrm{Ni}-\mathrm{W} / \mathrm{Al}_{2} \mathrm{O}_{3}$ may be more favorable for the diffusions of reactants and products compared with $\mathrm{Ni}-\mathrm{Mo} / \mathrm{Al}_{2} \mathrm{O}_{3}$ and $\mathrm{Ni}-\mathrm{W} / \mathrm{SiO}_{2}$, especially for the diffusion of coal-derived heavy oil. Since HDN and HDA activities are dependent not only on the physical surface area but also on the other surface physicochemical properties of the catalyst. $\mathrm{NH}_{3}-$ TPD and $\mathrm{H}_{2}-$ TPR showed that the acidities and the amount of the reducible sulfur species of metal sulfide followed the same order: $\mathrm{Ni}-\mathrm{W} / \mathrm{Al}_{2} \mathrm{O}_{3}>\mathrm{Ni}-\mathrm{W} / \mathrm{SiO}_{2}>\mathrm{Ni}-\mathrm{Mo} / \mathrm{Al}_{2} \mathrm{O}_{3}$. The activity evaluation results showed that the stability of heavy oil after hydrotreatment, HDN and HDA activities also followed the same order: $\mathrm{Ni}-\mathrm{W} / \mathrm{Al}_{2} \mathrm{O}_{3}>\mathrm{Ni}-\mathrm{W} / \mathrm{SiO}_{2}>$ $\mathrm{Ni}-\mathrm{Mo} / \mathrm{Al}_{2} \mathrm{O}_{3}$. The relative hydrogenation activity of $\mathrm{Ni}-\mathrm{W}$ was higher than that of Ni-Mo. Such difference in hydrogenation may be attributed to the difference in the

Table 2. HDA activities of the three sulfided catalysts

\begin{tabular}{lccccc}
\hline & $\mathrm{HDA} /(\%)$ & $\mathrm{HDA}(\mathrm{bi}) /(\%)$ & $\mathrm{HDA}($ tri) $) /(\%)$ & $\mathrm{HDA}($ anthracene) / (\%) & HDA (phenanthrene) / (\%) \\
\hline $\mathrm{NiMo} / \mathrm{Al}_{2} \mathrm{O}_{3}$ & 50 & 51 & 50 & 49 & 55 \\
$\mathrm{NiW} / \mathrm{Al}_{2} \mathrm{O}_{3}$ & 58 & 56 & 61 & 55 & 74 \\
$\mathrm{NiW} / \mathrm{SiO}_{2}$ & 50 & 50 & 55 & 49 & 61 \\
\hline
\end{tabular}


nature of active sites. Laetitia Oliviero proposed that the activity pattern of NiMo catalysts in HDS and in HDN results from the synergy between nickel and molybdenum in contact with each other on an adequate support, after sulfidation..$^{23}$ Then, the synergy effect between $\mathrm{Ni}$ and $\mathrm{W}$ is stronger than that of Ni and Mo. All the results above indicate that the higher hydrogenation activity of sulfided catalysts for coal-derived heavy oil upgrading is associated not only with the nature of active sites and larger pore size but also with the strong acidic sites, metal sulfide crystallite size and the formation of $\mathrm{S}$ anion vacancies. The orders of HDN and HDA activities are correlated to the orders of the strong acid sites and the amount of the reducible sulfur species of metal sulfide for three sulfided catalysts. This result indicates that the activities of sulfided catalysts are associated mainly with the nature of active sites, acidity and the amount of the reducible sulfur species of metal sulfide. The findings of the present study provide useful information for the development of better catalysts for the efficient HDN and HDA of coal-derived heavy oil.

\section{Conclusions}

HO derived from the direct coal liquefaction process of Shengli coal was hydrotreated in the presence of Mo-based or W-based sulfided catalyst at $400{ }^{\circ} \mathrm{C}$. The results suggest that the active phase and type of support significantly affect the HDN and HDA activities. The W-based sulfided catalysts had high hydrogenating activity. Higher catalytic activities were found on the $\mathrm{Al}_{2} \mathrm{O}_{3}$ than on $\mathrm{SiO}_{2}$ supported catalysts. The HDN and HDA activities of sulfided $\mathrm{Ni}-\mathrm{W} / \mathrm{Al}_{2} \mathrm{O}_{3}$ were about $60 \%$ and $58 \%$ at $400{ }^{\circ} \mathrm{C}$ and initial $5 \mathrm{MPa} \mathrm{H}_{2}$ respectively. $\mathrm{Ni}-\mathrm{W} / \mathrm{Al}_{2} \mathrm{O}_{3}$ had better hydrogenation activity towards triaromatics, especially for the hydrogenation of phenanthrene (the activity increases about $19 \%$ compared to that of $\mathrm{Ni}-\mathrm{Mo} / \mathrm{Al}_{2} \mathrm{O}_{3}$ ). The activities of sulfided catalysts are associated mainly with the nature of active sites, acidity, metal sulfide crystallite size and the amount of the reducible sulfur species of metal sulfide.

\section{Acknowledgments}

This work was supported by the Natural Scientific Foundation of China (20876001, 20776001, 20936007), the National High Technology Research and Development Program of China (973 Program 2011CB201300 and 863 Program 2007AA06Z113) and the State Key Laboratory of Coal Conversion (Grant No. 09-904). The authors express their grateful appreciation to the financial support from the Provincial Innovative Group for Processing \& Clean
Utilization of Coal Resource and Innovative Research Team in Anhui University of Technology.

\section{References}

1. Liu, Z.; Shi, S.; Li, Y.; Chem. Eng. Sci. 2010, 65, 12.

2. Perot, G.; Catal. Today 1991, 10, 447.

3. Dorbon, M.; Ignatiadis, I.; Schmitter, J. M.; Arpino, P.; Guichon, G.; Toulhoat, H.; Huc, A.; Fuel 1984,73, 565.

4. Fathoni, A. Z.; Batts, B. D.; Energy Fuels 1992, 6, 681.

5. Stanislaus, A.; Cooper, B. H; Catal. Rev. - Sci. Eng. 1994, 36, 75.

6. Liaw, S.; Keogh, R.; Thomas, G.; Davis, B.; Energy Fuels 1994, 8,581 .

7. Sumbogo Murtia, S. D.; Choia, K.; Sakanishib, K.; Okumac, O.; Koraia, Y.; Mochida, I.; Fuel 2005, 84,135.

8. Sarbak, Z.; Lewandowski, M.; Appl. Catal., A 2001, $208,317$.

9. Raje, A.; Liaw, S.; Chary, K.; Davis, B.; Appl. Catal., A 1995, 123, 229.

10. Liaw, S.; Lin, R.; Raje, A.; Davis, B.; Appl. Catal., A 1997, 151, 423.

11. Raje, A.; Liaw, S.; Srinivasan, R.; Davis, B.; Appl. Catal., A 1997, 150, 297.

12. Liaw, S.; Raje, A.; Thomas, G.; Davis, B.; Appl. Catal., A 1997, $150,343$.

13. Ferdous, D.; Dalai, A. K.; Adjaye, J.; Ind. Eng. Chem. Res. 2006, 45, 544.

14. Yasuda, H.; Higo, M.; Yoshitomi,S.; Sato, T.; Imamura, M.; Matsubayashi, H.; Shimada, H.; Nishijima, A.; Yoshimura, Y.; Catal. Today 1997, 39, 77.

15. Rodriguez-Castellón, E.; Jiménez-López, A.; Eliche-Quesada, D.; Fuel 2008, 87, 1195.

16. Ding, L.; Zheng, Y.; Zhang, Z.; Ring, Z.; Chen, J.; J. Catal. 2006, 241, 435.

17. van Veen, R. A. J.; Colijn, M. A.; Hendriks, P. A. J. M.; van Welsenes, A. J.; Fuel Process. Technol. 1993, 35, 137.

18. Ferdous, D.; Dalai, A. K.; Adjaye, J.; Appl. Catal., A 2004, 260 , 153.

19. Ding, L.; Zheng, Y.; Zhang, Z.; Ring, Z.; Chen, J.; Appl. Catal., A 2007, 319, 25.

20. Nag, N. K.; Fraenkel, D.; Moulijn, J. A.; Gates, B. C.; J. Catal. 1980, 66, 162.

21. Begon, V.; Suelves, I.; Herod,A. A.; Dugwell, D. R.; Kandiyoti, R.; Fuel 2000, 79, 1423.

22. Absi-Halabi, M.; Stanislaus, A.; Al-Dolama, K.; Fuel 1998, 77, 787.

23. Rocha, A. S.; Faro Jr., A. C.; Oliviero, L.; Gestel, J. V.; Maugé, F.; J. Catal. 2007, 252, 321.

Submitted: July 31, 2010

Published online: February 17, 2011 